\title{
Disposition kinetic and bioavailability of florfenicol in buffalo calves
}

\author{
A. A. M. El-Gendy', M. A. Tohamy', M. Ismail ${ }^{2}$ \\ ${ }^{1}$ Pharmacology Department Faculty of Veterinary Medecine Beni-suef University, Beni-suef, Egypt \\ ${ }^{2}$ Pharmacology Department Faculty of Veterinary Medecine Cairo University, Cairo, Egypt
}

\begin{abstract}
The Pharmacokinetics of florfenicol was studied in buffalo calves following single intravenous and intramuscular administration of $20 \mathrm{mg} \mathrm{kg}^{-1}$ b.wt. Florfenicol concentration in both serum and urine were determined by microbiological assay using Bacillus subtilis (ATCC 6633) as test organism. After intravenous injection the serum florfenicol concentration time course obeys two-compartment open model with distribution $\left(t_{0.5(\alpha)}\right)$ and elimination $\left(t_{0.5(\beta)}\right)$ half lives of $0.381 \pm 0.004$ and $2.89 \pm 0.263$ $h$., respectively. Total body clearance $\left(C L_{B}\right)$ and steady state volume of distribution $\left(V_{\mathrm{ss}}\right)$ were $3.6 \pm 0.30 \mathrm{ml} \mathrm{kg} \mathrm{min}^{-1}$ and $1.70 \pm 0.0101 \mathrm{~kg}^{-1}$, respectively. After intramuscular administration the observed mean peak serum concentration $\left(C_{\max }\right)$ was $2.32 \pm 0.052 \mu \mathrm{g} \mathrm{ml} \mathrm{m}^{-1}$ achieved after maximum time $\left(\mathrm{T}_{\max }\right)$ of one hour postinjection. The systemic bioavailability after intramuscular administration was $27.43 \%$ and the plasma protein binding was $13.5 \%$.
\end{abstract}

Florfenicol is a new broad-spectrum antibiotic belonging to the thiamphenicol and chloramphenicol. It is a fluorinated derivative of thiamphenicol. A major mechanism of bacterial resistance development to both chloramphenicol and thiamphenicol involves the presence of chloramphenicol acetyl-transferase (CAT) in resistant organisms. The structural modification in the molecule of florfenicol, substitution of a fluorine atom for the hydroxyl group at C3 site, prevents acetylation by CAT (Sams, 1995). Consequently, florfenicol is active against many chloramphenicol resistant strains such as Klebsiella pneumoniae, Enterobacter cloacae, Shigella dysenteriae, Salmonella typhi, Escherichia coli, Staphylococcus aureus, Proteus vulgaris and Haemophilus somnus (Neu and $\mathrm{Fu}, 1980$; Syriopoulou et al., 1981 and Varma et al., 1986). Florfenicol is recommended for treatment of respiratory infections in cattle (Martel, 1994 and Varma et al., 1991).

The pharmacokinetics of florfenicol have been studied in pigs (Voorspoels et al., 1999), horses (Mckellar and Varma, 1996), cattle (Lobell et al., 1994; De Craene et al., 1997 and Varma et al., 1998), goats (Atef et al., 2000, 2001 and Ali et al., 2003), camel and sheep (Ali et al., 2003), chickens (Afifi and Abo El-Sooud, 1997 and Shen et al., 2002) and ducks (ElBanna, 1998).

The aim of the present study was to determine the pharmacokinetic parameters and bioavailability of florfenicol in buffalo calves in order to establish adequate dose regimen for potential clinical use in buffalo calves infection with susceptible organisms.

\section{Material and Methods}

Drug. Florfenicol (Nuflor $\AA$, Schering-plough Animal Health, La Grindoliere, France).

Animals. Five healthy buffalo calves weighing $78-84 \mathrm{~kg} \mathrm{~b}$. wt (6 month old) were used. Animals were kept under good hygienic condition, feed on hay and concentrated mixture and water ad-libitum. None of the calves were treated with antibiotics for one month prior to the trial. Experimental design: Animals were given a single intravenous (i. v.) dose of $20 \mathrm{mg}$ $\mathrm{kg}^{-1}$ florfenicol into the right jugular vein. Blood samples $(10 \mathrm{ml}$ each) were collected from the left jugular vein just before drug administration and at 5, 10, 15, 30-minutes and 1, 2, 4, 6, 8, 12 and 24-hour after drug administration. The blood was allowed to clot at room temperature, then the serum was separated by centrifugation at $3000 \mathrm{rpm}$ for 15 minutes. Each serum sample obtained was divided into two parts, the first was used for determination of florfenicol concentration and the second part was used for creatinine assay. Serum samples were stored at $20^{\circ} \mathrm{C}$ until assayed. After a washout period of two weeks, animals injected intramuscularly with the same dose into the deep gluteal muscle of hindquarter and blood was collected and processed as mentioned above.

Urine samples. Each calf was catheterized using folly catheter (No. 14). The bladder was emptied 
before drug administration. Urine samples were hours after drug administration for both routes. All urine samples were divided into two parts, the first was used for determination of florfenicol concentration and the second part was used for creatinine assay. Urine samples were stored at $-20^{\circ} \mathrm{C}$ until used for assessment.

Drug assay. Florfenicol concentrations in serum and urine samples were determined by the microbiological assay method described by (Arret et al. 1971) using Bacillus subtilis (ATCC 6633 ) as test organism. Standard curves were constructed using antibacterial-free sera and urine collected from calves. Six wells, $8 \mathrm{~mm}$ in diameter were cut at equal distances in standard Petri dishes containing $25 \mathrm{ml}$ seeded agar. The wells were filled with $100 \mu \mathrm{l}$ of either the test samples or florfenicol standards. The plates were incubated at $37^{\circ} \mathrm{C}$ for $16-18$ hours. The inhibition zone diameters were measured and the florfenicol concentrations in the test samples were calculated from the standard curve. The lower detectable limit of the florfenicol assay was $0.07 \mathrm{ug} \mathrm{ml}^{-1}$. Semilogarithmic plots of the inhibition zone diameter versus standard florfenicol concentrations in serum were linear with typical correlation coefficient of 0.990 (for the standard curve).

The extent of protein binding of the drug was determined in vitro using the method of (Craig and Suh, 1980) with florfenicol concentrations of $40,25,20,10,5,2.5,1.25,0.625,0.313$, 0.156 and $0.078 \mathrm{ug} \mathrm{ml}^{-1}$ in serum according to the following equation:

Protein binding $\%=$ zone of inhibition in buffer-zone of inhibition in serum x 100 Zone of inhibition in buffer

Creatinine concentrations in serum and urine samples were estimated according to the method previously described (Siest et al., 1985) to determine the creatinine clearance. Florfenicol clearance and creatinine clearance ratio was calculated to determine the pathway of florfenicol elimination through the kidney.

Pharmacokinetic analysis. The pharmacokinetic parameters were calculated according to the metod described by (Baggot, 1978). The experimental constants (A, B, $\alpha$ and $\beta$ ) were used to calculate the actual pharmacokinetic rate constants $\left(\mathrm{K}_{12}, \mathrm{~K}_{21}\right.$ and $\left.\mathrm{K}_{\mathrm{cl}}\right)$ which are associated with the mathematical model. The volume of distribution of the central compartment $\left(\mathrm{V}_{\mathrm{c}}\right)$ was obtained from the equation:

$$
\operatorname{Vc}\left(\mathbf{m g ~ k g}^{-1}\right)=\frac{\text { Dose }\left(\mathrm{ug} \mathrm{kg}^{-1}\right)}{\mathrm{C}^{\mathrm{o}}\left(\mathrm{ug} \mathrm{ml} \mathrm{H}^{-1}\right)}
$$

collected prior and at $0.5,1,2,4,6,8,12$ and 24 Where. $C^{o}$ is the drug concentration at the time of i. v. injection $\left(\mathrm{C}^{\mathrm{o}}=\mathrm{A}+\mathrm{B}\right)$. While $\mathrm{A}$ and $\mathrm{B}$ are zero time serum drug concentration intercepts.

Body clearance $\left(\mathrm{CL}_{\mathrm{B}}\right)$ expressed in $\mathrm{ml} \mathrm{kg}^{-1} \mathrm{~min}^{-1}$ was calculated by the equation:

$$
\mathrm{CL}_{\mathrm{B}}=\mathrm{Kel} \mathrm{x} \mathrm{Vc}
$$

Bioavailability \% (F) $=$ AUC (intramuscular) $\times 100$

$$
\text { AUC (intravenous) }
$$

where AUC is the area under the serum

concentration time curves (AUC $\left.=\mathrm{A} \alpha^{-1}+\mathrm{B} \beta^{-}\right)$.

\section{Results}

The mean serum concentrations time course of florfenicol after i. v. and i. m. administration are depicted in (Fig. 1). Pharmacokinetic parameters are showed in (Table 1). After i. v. administration of $20 \mathrm{mg} \mathrm{kg}^{-1}$ b. wt., the florfenicol serum concentration time data obeys two-compartment open model. The distribution and elimination half-lives were $0.381 \pm 0.004$ and $2.89 \pm 0.263 \mathrm{~h}$., respectively. The steady state volume of distribution $\left(\mathrm{Vd}_{\mathrm{ss}}\right)$ was $1.70 \pm$ $0.0101 \mathrm{~kg}^{-1}$ and mean residence time was $7.87 \pm$ $0.898 \mathrm{~h}$.

Florfenicol was rapidly absorbed after i. m. administration with absorption half life $\left(\mathrm{t}_{0.5}(\mathrm{ab})\right)$ $0.59 \pm 0.02 \mathrm{~h}$. Peak serum concentration $\left(\mathrm{C}_{\max }\right)$ was $2.32 \pm 0.052 \mu \mathrm{g} \mathrm{ml}$ achieved after maximum time $\left(\mathrm{T}_{\max }\right)$ of one hour post administration. The drug was slowly eliminated from blood after i. m. than i. v. administration.

Florfenicol was found to be excreted at high concentration in urine of buffalo calves following both i. v. and i. m. routes and extends up to $24 \mathrm{~h}$ post administration as shown in (Table 2), also the florfenicol to creatinine clearance was less than one as shown in (Table 3 ). The systemic bioavailability of florfenicol after i. m. injection was $27.43 \%$ and the extent of plasma protein binding was $13.50 \%$.

\section{Discussion}

In this study, microbiological assay was used to determine florfenicol concentration in serum and urine of buffalo calves. This method did not, however, distinguish between the active metabolites and parent compound. Because the metabolites are microbiologically active, their presence may not necessarily interfere with determination of therapeutic dosage regimen (Sams, 1994).

Florfenicol pharmacokinetics in buffalo calves have been described by a twocompartment open model after the single i. v. dose of $20 \mathrm{mg} \mathrm{kg}^{-1} \mathrm{~b}$. wt. Our findings are 
Table (1): Pharmacokinetic parameters following intravenous and intramuscular administration of $20 \mathrm{~m} \mathrm{~kg}^{-1}$ b. wt. florfenicol in buffalo calves $(n=5)$.

\begin{tabular}{|c|c|c|c|c|c|}
\hline \multicolumn{6}{|c|}{ Pharmacokinetic parameters after } \\
\hline \multicolumn{3}{|c|}{ i. $v$} & \multicolumn{3}{|c|}{ i. $\mathbf{m}$} \\
\hline Parameter & Unit & Mean \pm SE & Parameter & Unit & Mean \pm SE \\
\hline $\mathrm{Cp}^{\circ}$ & $\mu \mathrm{g} \mathrm{ml}^{-1}$ & $42.22 \pm 0.879$ & $\mathbf{A}$ & $\mu \mathrm{g} \mathrm{ml}^{-1}$ & $1.47 \pm 0.102$ \\
\hline $\mathbf{A}$ & $\mu \mathrm{g} \mathrm{ml}^{-1}$ & $23.40 \pm 1.364$ & B & $\mu \mathrm{g} \mathrm{ml}^{-1}$ & $2.52 \pm 0.097$ \\
\hline$\alpha$ & $h^{-1}$ & $1.82 \pm 0.192$ & $\mathbf{K}_{\mathbf{a b}}$ & $h^{-1}$ & $1.18 \pm 0.060$ \\
\hline $\mathbf{t}_{0.5(\alpha)}$ & h. & $0.381 \pm 0.004$ & $t_{0.5(a b)}$ & h. & $0.59 \pm 0.02$ \\
\hline B & $\mu \mathrm{g} \mathrm{ml}^{-1}$ & $18.82 \pm 0.485$ & $\mathbf{K}_{\mathrm{el}}$ & $\mathrm{h}^{-1}$ & $0.08 \pm 0.006$ \\
\hline$\beta$ & $h^{-1}$ & $0.24 \pm 0.010$ & $\mathbf{t}_{0.5(\mathrm{el})}$ & h. & $8.66 \pm 0.703$ \\
\hline $\mathbf{t}_{0.5(\beta)}$ & h. & $2.89 \pm 0.263$ & $\mathbf{C}_{\max }$ & $\mu \mathrm{g} \mathrm{ml}^{-1}$ & $2.32 \pm 0.052$ \\
\hline$K_{12}$ & $\mathrm{~h}^{-1}$ & $0.66 \pm 0.061$ & $\mathbf{T}_{\max }$ & h. & $1.00 \pm 0.00$ \\
\hline $\mathbf{K}_{21}$ & $\mathrm{~h}^{-1}$ & $0.94 \pm 0.081$ & MRT & h. & $8.72 \pm 0.779$ \\
\hline $\mathbf{K}_{\mathrm{el}}$ & $\mathrm{h}^{-1}$ & $0.46 \pm 0.071$ & AUC & ug $\mathrm{ml}^{-1} \mathrm{~h}^{-1}$ & $25.84 \pm 0.633$ \\
\hline$V d_{(s s)}$ & $1 \mathrm{~kg}^{-1}$ & $1.70 \pm 0.010$ & $\mathbf{F}$ & $\%$ & 27.43 \\
\hline Vc & $1 \mathrm{~kg}^{-1}$ & $0.47 \pm 0.040$ & & & \\
\hline $\mathbf{A U C}$ & $\mu \mathrm{g} \mathrm{ml}^{-1} \mathrm{~h}^{-1}$ & $94.20 \pm 1.93$ & & & \\
\hline MRT & h. & $7.87 \pm 0.889$ & & & \\
\hline $\mathrm{CL}_{\mathbf{B}}$ & $\mathrm{ml} \mathrm{kg}{ }^{-1} \min ^{-1}$ & $3.60 \pm 0.026$ & & & \\
\hline
\end{tabular}

**Protein binding $13.5 \%$.

Table (2): Urine concentration (Mean $\pm \mathrm{SE}$ ) of florfenicol following intravenous and intramuscular administration of $20 \mathrm{mg} \mathrm{kg}^{-1} \mathrm{~b}$. wt. in buffalo calves $(\mathrm{n}=5)$.

\begin{tabular}{|c|c|c|}
\hline \multirow{2}{*}{ Time (h) } & \multicolumn{2}{|c|}{ Urine concentration of florfenicol ug ml ${ }^{-1}$ after } \\
\hline & i.v & i.m \\
\hline 0.5 & $1043.33 \pm 90.99$ & $121.45 \pm 4.27$ \\
\hline 1 & $617.21 \pm 22.41$ & $256.87 \pm 13.82$ \\
\hline 2 & $330.21 \pm 28.95$ & $171.07 \pm 21.43$ \\
\hline 4 & $279.84 \pm 20.92$ & $103.84 \pm 14.08$ \\
\hline 6 & $147.95 \pm 19.53$ & $74.03 \pm 4.95$ \\
\hline 8 & $105.11 \pm 30.75$ & $42.27 \pm 2.73$ \\
\hline 12 & $16.01 \pm 3.24$ & $33.70 \pm 0.86$ \\
\hline 24 & $6.71 \pm 0.613$ & $11.05 \pm 0.55$ \\
\hline
\end{tabular}

Table (3): Florfenicol / creatinine clearance ratio following intravenous and intramuscular administration of florfenicol at a dose of $20 \mathrm{mg} \mathrm{kg}^{-1} \mathrm{~b}$.wt. in buffalo calves (n=5).

\begin{tabular}{|c|c|c|c|c|c|c|}
\hline \multirow[b]{2}{*}{$\begin{array}{c}\text { Time } \\
\text { (h) }\end{array}$} & \multicolumn{3}{|c|}{ i. $\mathbf{v}$} & \multicolumn{3}{|c|}{ i. $\mathbf{m}$} \\
\hline & $\begin{array}{c}\text { Florfenicol } \\
\text { clearance ml } \\
\mathrm{min}^{-1} 10 \mathrm{~kg}^{-1}\end{array}$ & $\begin{array}{l}\text { Creatinine } \\
\text { clearance ml } \\
\text { min }^{-1} 10 \mathrm{~kg}^{-1}\end{array}$ & Ratio & $\begin{array}{l}\text { Florfenicol } \\
\text { clearance ml } \\
\text { min }^{-1} 10 \mathrm{~kg}^{-1}\end{array}$ & $\begin{array}{l}\text { Creatinine } \\
\text { clearance } \mathrm{ml} \\
\mathrm{min}^{-1} 10 \mathrm{~kg}^{-1}\end{array}$ & Ratio \\
\hline 0.5 & $1.53+0.12$ & $33.85+2.50$ & $0.045+0.0002$ & $7.03+0.235$ & $22.55+2.25$ & $0.312+0.016$ \\
\hline 1 & $7.17+0.512$ & $26.09+2.31$ & $0.275+0.015$ & $8.69+0.651$ & $20.76+1.88$ & $0.419+0.35$ \\
\hline 2 & $14 . \overline{5 \pm} 1.23$ & $24.91+2.35$ & $0.582 \pm 0.035$ & $20.33+1.052$ & $20.34+2.05$ & $0.999 \pm 0.051$ \\
\hline 4 & $15.39+1.33$ & $18.97+1.56$ & $0.811+0.057$ & $20.01+0.956$ & $20.28+1.99$ & $0.987+0.06$ \\
\hline
\end{tabular}

similar to those reported in calves (Varma et al., 1986; Adams et al., 1987 and De Craene et al., 1997). However, (Bretzlaff et al., 1987; Lobell et al., 1994 and Soback et al., 1995) found that the disappearance of florfenicol from the serum after i. v. dose was described adequately by a triexponential terms. The difference between biand tri-exponential terms is unlikely to be of clinical importance.

The initial distribution phase was rapid with $\left(\mathrm{t}_{0.5(\alpha)}\right)$ of $0.381 \mathrm{~h}$. Similar finding was recorded in calves $0.380 \mathrm{~h}$ (De Craene et al., 1997). The mean elimination half-life $\left(\mathrm{t}_{0.5(\beta)}\right) 2.89$ h., which is similar to that reported in other studies: 2.865 h in veal calves (Varma et al., 1986) and also, closely approaches value of $2.77 \mathrm{~h}$ in calves (Varma et al., 1991) while, longer than the values that are recorded in goats 1.185 (Ali et al., 2003) and $0.973 \mathrm{~h}$ (Atef et al., 2000) and in sheep $1.01 \mathrm{~h}$ (Lane et al., 2004). This variation may be due to species difference. The mean body clearance $\left(\mathrm{CL}_{\mathrm{B}}\right)$ of $3.6 \pm 0.36 \mathrm{ml} \mathrm{kg} \mathrm{min}^{-1}$ 

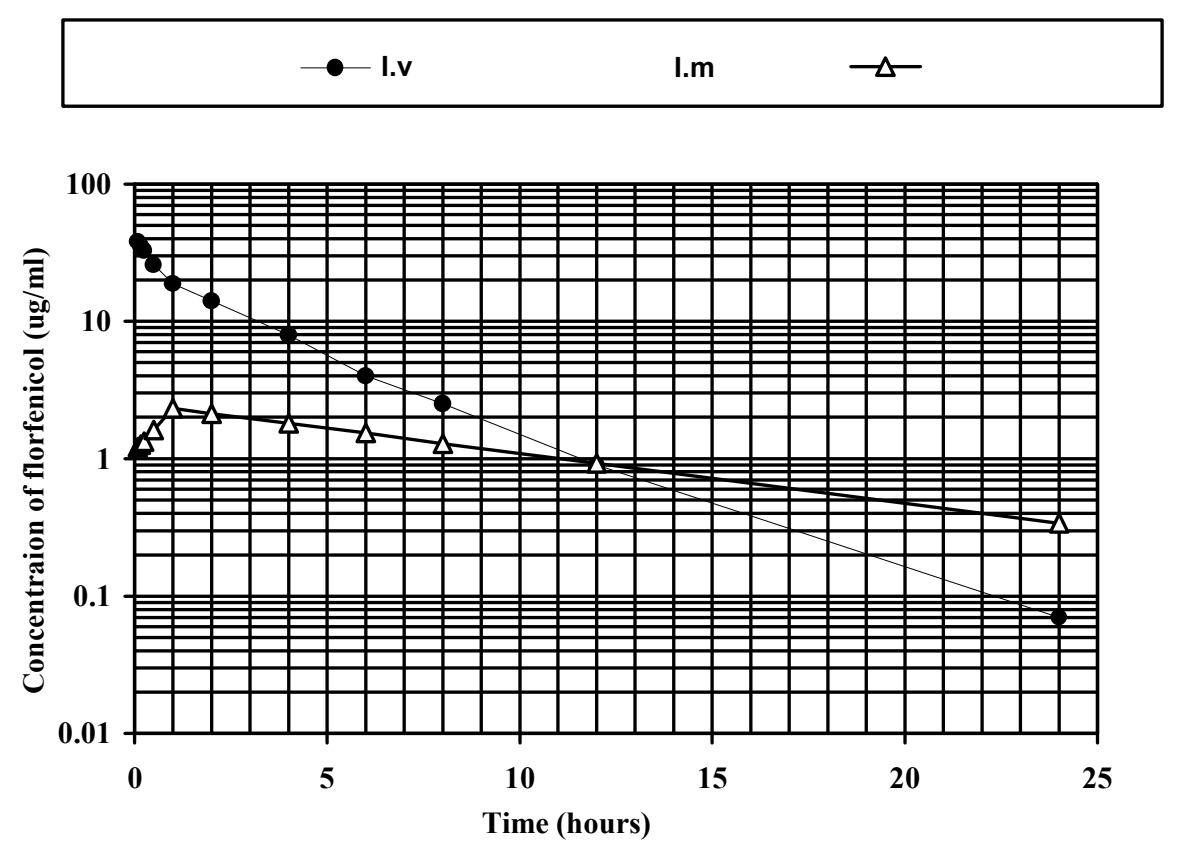

Fig. (1): Semilogarithmic graph depicting the time-concentration of florfenicol in serum of buffalo calves after a single intravenous and intramuscular injection of $20 \mathrm{mg} / \mathrm{kg}$ b.wt.

was similar to that is reported in calves $3.57 \mathrm{ml}$ $\mathrm{kg}^{-1} \min ^{-1}$ (Lobell et al., 1994) and $3.67 \mathrm{ml} \mathrm{kg}^{-1}$ $\min ^{-1}$ (De Craene et al., 1997), in goats $4.5 \mathrm{ml}$ $\mathrm{kg}^{-1} \min ^{-1}$ (Ali et al., 2003) and in sheep 6.1 and $4.17 \mathrm{ml} \mathrm{kg}^{-1} \min ^{-1}$ (Lane et al., 2004 and Shen et al., 2004 respectively). The longer $t_{0.5}(\beta)$ and smaller $C_{B}$ for the drug in buffalo calves compared to those reported in other species are expected. An allometric relationship exists for physiological functions in particular hepatic blood flow, correlated with body weight across different species (Adolph, 1949). By applying principles of allometry to pharmacokinetic parameters (Riviere et al., 1997), the finding of larger clearance for the species with the smaller body weight may be expected. The shorter elimination half-life might be attributed to higher glucuronyl transferase activity in goats (Short et al., 1988).

The volume of distribution at steady state (Vdss) is an accurate indication for the diffusion of the drug in the body tissues (Gilman et al., 1980 and Galinsky and Svensson, 1995). Florfenicol showed Vdss of $1.70 \pm 0.0101 \mathrm{~kg}^{-1}$, in buffalo calves, which is similar to its kinetic behaviour in healthy sheep 1.86 and $1.711 \mathrm{~kg}^{-1}$ (Shen et al., 2004). On the other hand, florfenicol showed larger Vdss in broiler chickens (range: $3.50-5.11 \mathrm{1} \mathrm{kg}^{-1}$ ) as described by (Shen et al. 2003 and Afifi and Abo ElSooud, 1997) and in Muscovy ducks $5.151 \mathrm{~kg}^{-1}$ (El-Banna, 1998). This may be due to individual, anatomical or physiological variations between the different individuals and species.

Florfenicol was rapidly absorbed following the i.m. administration with an absorption half-life $\left(\mathrm{t}_{0.5}\right.$ (ab) $) 0.59 \mathrm{~h}$. This result is in agreement with that is reported in goats (Atef et al., 2000).

The observed mean peak plasma concentration $\left(\mathrm{C}_{\text {max. }}\right)$ of florfenicol was $2.32 \mu \mathrm{g}$ $\mathrm{ml}^{-1}$ achieved at $\left(\mathrm{T}_{\text {max. }}\right)$ one hour post-injection. Our finding is similar to that is reported in lactating cows $2.3 \mu \mathrm{g} \mathrm{ml}^{-1}$ (Soback et al., 1995), but lower and shorter than the values reported by (Lobell et al. 1994) for the florfenicol after i. m. administration to calves and assayed by HPLC $\left(\mathrm{C}_{\max } 3.21 \mu \mathrm{g} \mathrm{ml}^{-1}\right.$ at $\left.3.33 \mathrm{~h}\right)$. The differences in kinetic parameters are relatively common and are frequently related to interspecies variation, assay method used, extent of blood sampling and 
the health status of the animals (Haddad et al., 1985).

Florfenicol showed longer $t_{0.5 \text { (el) }}$ after i. m. administration than i. v. dosing, as it would be slowly released from the site of injection. Intramuscular administration can, therefore, provide an extended period with approximately even concentrations of the drug in the blood.

In this study, the mean level in urine declined after i. v. administration from 1043.33 $\mu \mathrm{g} \mathrm{ml}^{-1}$ at $0.5 \mathrm{~h}$ to $6.71 \mu \mathrm{g} \mathrm{ml}^{-1}$ after $24 \mathrm{~h}$., while following i. $\mathrm{m}$. administration the drug reached its maximum level $256.87 \mu \mathrm{g} \mathrm{ml}^{-1}$ after one-hour and decreased to its lowest level $11.05 \mu \mathrm{g} \mathrm{ml}^{-1}$ after 24-hour. These values closely approach those in veal calves following i. v. and oral dosing, respectively (Varma et al., 1986). The higher concentrations of florfenicol were found in urine, indicating that florfenicol may be an efficacious drug for treating urinary tract infections caused by susceptible organisms.

The ratios between florfenicol clearance to creatinine clearance was less than one, indicating that the glomerular filtration is the main pathway for florfenicol elimination through the kidney with a variable amount reabsorbed back to blood (Akhtar et al., 1997). The systemic bioavailability (F) of florfenicol in buffalo calves after i. m. injection was $27.43 \pm 0.388 \%$. This value was similar to that is recorded in sheep $27 \%$ (Lane et al., 2004) but higher than that is recorded in cattle $19 \%$ (Sanders et al., 1988 ) and lower than that in lactating cows $38 \%$ (Soback et al., 1995), calves (range: 59.3 - 106 \%) (Lobell et al., 1994) and in goats $60.88 \%$ (Ali et al., 2003) and $65.718 \%$ (Atef et al., 2000). Variability in absorption from the i. m. site might be due to differences in regional blood flow in the different muscle tissue sites which is the major determinant.

In vitro protein binding percentage of florfenicol in serum of buffalo calves was 13.50 $\pm 0.164 \%$. This value was similar to its value in calves $13.2 \%$ (Lobell et al., 1994). This finding indicates that the drug is moderately low bound to serum proteins and is consistent with its high steady-state volume of distribution and extensive distribution in tissues.

The minimum inhibitory concentrations $\left(\mathrm{MIC}_{\mathrm{s}}\right)$ of florfenicol for bacteria isolates from buffalo calves have not yet been determined. Based on MIC data studied on bacteria from calves and cows, the $\mathrm{MIC}_{\mathrm{s}}$ of florfenicol for pasteurella multocida and pasteurella haemolytica ranges from 0.25 to $2.0 \mu \mathrm{g} \mathrm{ml}^{-1}$ with the majority values at $1.0 \mu \mathrm{g} \mathrm{ml}^{-1}$ (Varma et al., 1986), $0.25 \mu \mathrm{g} \mathrm{ml}^{-1}$ ( $\mathrm{MIC}_{90}$ ) is also the level of florfenicol at which $90 \%$ of haemophilus somnus inhibited (De Craene et al., 1997). In vitro, florfenicol is more active than chloramphenicol against $H$. somnus (Martel, 1994), a major pathogen in bovine meningitis (George, 1996). Florfenicol has a higher therapeutic efficacy in bovine respiratory diseases than other commonly used antibacterials, including amoxicillin, enrofloxacin and oxytetracycline (De Haas et al., 1995; Libersa et al., 1995 and Lockwood et al., 1995).

In this study, the time of plasma concentration above $0.25 \mu \mathrm{g} \mathrm{ml}^{-1}$ is approx-imately 24 h. Therefore, florfenicol should be given $20 \mathrm{mg}$ $\mathrm{kg}^{-1}$ b. wt. once daily to maintain therapeutic concentrations in treatment of respiratory infections in buffalo calves. Also, the higher concentrations recovered in urine indicates that the drug would be efficacious in treatment of many Gram-negative urinary tract pathogens.

\section{References}

Adams, P. E.; Varma, K. J.; Powers, T. E. and Lamendola, J. F. (1987): Tissue concentrations and pharmacokinetics of florfenicol in male veal calves given repeated doses. Am. J. Vet. Res., 12: 1725-1732.

Adolph, E .F. (1949): Quantitative relations in the physiological constitutions of mammals. Sci., 109: 579585. Afifi, N. A. and Abo El-Sooud, K. A. (1997): Tissue concentrations and pharmacokinetics of florfenicol in broiler chickens. Br. Poult. Sci., 38: 425-428.

Akhtar, P.; Nawaz, M.; Iqbal, T. and Nawaz, R. (1997): Renal clearance of creatinine, urea, paramino hippuric, sodium, potassium and chloride during summer and winter seasons in goats. Vet. Arch., 67 (6): 267-275.

Ali, B. H.; Al-qarawi, A. A and Hashaad (2003): Comparative plasma pharmacokinetics and tolerance of florfenicol following intramuscular and intravenous administration to camels, sheep and goats. Vet. Res. Commun., 27: 475-483.

Arret, B.; Johnoson, D. P. and Kirshaum, A. (1971): Outline of details of microbiological assay of antibiotics: Second revision: J. Pharmaceut. Sci., 60: 1489-1694.

Atef, M.; EL-Gendi, A. Y.; Amer, A.M. and Abd El-Aty, A. M. (2001): Disposition kinetics of florfenicol in goats by using two analytical methods. J. Vet. Med., 48: 129-136.

Atef M. EL-Gendi, A. Y.; Aziz, M. M.; Abd El-Aty, A. M. (2000): Pharmacokinetic properties of florfenicol in Egyptian goats. Dtsch Tierarztl Wochenschr. 107 (4): 14750.

Baggot, J. D. (1978): Some aspects of clinical pharmacokinetics in veterinary medicine. J. Vet. Therap., 1: 5-18.

Bretzlaff, K. N.; Neff-Davis, C. A.; Ott, R. S.; Koritz, G. D.; Gustafsson, B. K. and Davis, I. F. (1987): Flofenicol in non-lactating dairy cows pharmacokinetics binding to plasma proteins and effects on phagocytosis by blood neutrophils. J. Vet. Pharmacol. Therapeut., 10: 233-240.

Craig, A. W. and Suh, B. (1980): Protein binding and the antibacterial effects: Methods for determination of protein 
binding, in: Lorian, V. (ed.) Antibiotics in Laboratory Medicine, pp. 265-297 (Baltimore, Maryland, Williams and Wilkins).

De Craene, B. A.; Deprez, P.; D'haese, E.; Nelis, H. J.; Vandn Bosche, W. and Delenheer, A. P. (1997): Pharmacokinetics of florfenicol in cerebrospinal fluid and plasma of calves. Antimicrob. Agents Chem., 41 (9): 19911995.

De Haas, V., Lockwood, P. W., Katz, T and Varma, K. J. (1995): Efficaité du florfenicol dans le traitement du complexe des maladies respiratories des bovines: resultants des essays cliniques realizes en Europe. In Symposium International sur les Maladies Respiratories Bovine: Récents Progrés Thérapeutiques. Schering-Plough. Union, N.J. pp 41.

EL-Banna, H. A. (1998): Pharmacokinetics of florfenicol in normal and pasteurella-infected Muscovy ducks. Br. Poult. Sci., 39: 492-496.

Galinsky, R. E. and Svensson, C. K. (1995): Basic pharmacokinetics. In: Remington (editor): The Science and Practice of Pharmacy, $19^{\text {th }}$ edition, pp. 724-740. Mack Publishing Company, Easton, Pennsylvania.

George, L. W. (1996): Thromboembolic meningoencephalitis (Haemophilus somnus infection. Sleeper calves). pp. 1092-1094. In B.P. Smith (ed.) Large animal internal medicine. $2^{\text {nd }}$ ed. Mosby, St. Louis, Mo.

Gilman, A. G.; Goodman, L. S. and Ghman, A. (1980): Goodman and Gilman's: The pharmacological basis of therapeutics, $6^{\text {th }}$ ed. (New York, MacMillian), pp. 21.

Haddad, N. S.; Pedersoli, W. M.; Ravis, W. R.; Fazeli, M. H. and Carson, R. L. (1985): Combined pharmacokinetics of gentamicin in pony mares after a single intravenous and intramuscular administration. Am. J. Vet. Res., 46: 2004-2007.

Lane V. M.; Villarroel, A.; Wetzlich, S. F.; Clifford, A.; Taylor, I. and Craigmill, A. L. (2004): Intravenous and subcutaneous pharmacokinetics of florfenicol in sheep. J. Vet. Pharmacol. Therap. 27 (4): 191-6.

Libersa, M.; Van Huffel, B.; Madelenat, A.; Dalle, S.; De Haas, V.; Lockwood, P. W. and Varma, K. J. (1995): Evaluation de l'efficacité d'un nouvel antibiotique le florfénicol (Nuflor ND) dans le traitement des maladies respiratories des bovines. Rec. Méd. Vét. 171: 39-44.

Lobell, R. D.; Varma, K. J.; Johnoson, J. C.; Sams, R. A.; Gerken, D. F. and Asheraft, S. M. (1994): Pharmacokinetics of florfenicol following intravenous and intramuscular doses to cattle. J. Vet. Pharmacol. Therap., 17: 253-258.

Lockwood, P. W.; DE Haas, V.; Katz, T. and Varma, K. J. (1995): Efficacité du florfenicol dans le traitement du complexe des maladies respiratories des bovines: résultas des essays cliniques realizes en Amérique du Nord. In Symposium International sur les Maladies Respiratories Bovines: Récents Progrés Thérapeutiques. ScheringPlough, Union, N.J., pp. 34.

Martel, J. L. (1994): Activité in vitro du florfénicol sur les bactéries pathogens du tractus respiratory de bovines en Europe. In Symposium International sur les Maladies Respiratories Bovines: Récents Progries Thérapeutiques. Schering-Plough. Union, N.J. pp.28.

Mckellar, Q. A. and Varma, K. J. (1996): Pharmacokinetics and tolerance of florfenicol in Equidae Eq. Vet. J.,
28 (3): 209-213.

Neu, H. C. and Fu, K. P. (1980): In vitro activity of Chloramphenicol and Thiamphenicol analogs. Antimicrob. Agents Chem., 18: 311-316.

Riviere J. E.; Martin-Jimenez, T.; Sundlof, S. F. and Carsigmill, A. L. (1997): Interspecies allometric analysis of the comparative pharmacokinetics of 44 drugs across veterinary and laboratory animal species. J. Vet. Pharmacol. Therap., 20: 453-463.

Sams, R. A. (1994): Florfenicol: Chemistry and metabolism of a novel broad-spectrum antibiotic. International Symposium on Bovine Respiratory Disease. New Therapeutic Advances, Bologna, Italy, pp. 13-17.

Sams, R.A. (1995): Chemistry and metabolism of a novelbroad-spectrum antibiotic. Tiererztliche Umschau. 50: 703707.

Sanders, P.; Guillot, P. and Murot, D. (1988): Pharmacokinetics of a long acting chloramphenicol formulation administered by intramuscular and subcutaneous routes in cattle. J. Vet. Pharmacol. Therap., 11 (2): 183-195.

Shen, J.; Hu, D.; Wu, X. and Coats, J. R. (2003): Bioavailability and pharmacokinetics of florfenicol in broiler chickens. J. Vet. Pharmacol. Therap., 26 (5): 337 41.

Shen, J.; Li, X.; Jlang, H. and Hsu, W. H. (2004): Bioavailability and pharmacokinetics of florfenicol in healthy sheep. J. Vet. Pharmacol. Therap., 27 (3): 163-8.

Shen, J.; Wu, X.; Hu, D. and Jlang, H. (2002): Pharmacokinetics of florfenicol in healthy and Escherichia coli-infected broiler chickens. Res. Vet. Sci., 73: 137-140.

Short, C. R.; Flory, W.; Hsieh, L. C.; Aranas, T.; OU, S. P. and Weissisger, J. (1988): Comparison of hepatic drug metabolizing enzyme activities in several agricultural species. Comp. Biochem. Physiol., (91 c): 419-424.

Siest, G.; Henny, J.; Schielc, F. and Young, D. S. (1985): Colorimetric determination of creatinine. Interpretation of clinical laboratory tests. $3^{\text {rd }}$ ed., London.

Soback, S.; Paape, M. J.; Filep, R. and Varma, K. J. (1995): Florfenicol pharmacokinetics in lactating cows after intravenous, intramuscular and intramammary administration. J. Vet. Pharmacol. Therap., 18: 413-417.

Syriopoulou, V. P.; Harding, A. L.; Goldmann, D. A. and Smith, A. L. (1981): In vitro antibacterial activity of florfenicol analogs of chloramphenicol and thiamphenicol. Antimicrob. Agents Chem., 19: 294-297.

Varma, K. J.; Adams, P. E.; Powers, T. E.; Powers, J. D. and Lamendola, J. F. (1986): Pharmacokinetics of florfenicol in veal calves. J. Vet. Pharmacol. Therap. 9: 412-425.

Varma, K. J.; Adams, P. E.; Powers, T. E. and Lamendola,J. F. (1998): Pharmacology, safety and clinical efficacy of Nuflor "florfenicol" following subcutaneous administration to cattle. Cattle practice, 6: 281-286.

Varma, K. J.; Sams, R. A.; Lobell, R. D. and Lockwood, P. W. (1991): Pharmacokinetics and efficacy of a new broad spectrum antibiotic, florfenicol in cattle. Acta Vet. Scand. Suppl., 87: 102-104.

Voorspoels, J. D.; D'Haese, B. A.; De Craene, B. A.; Vervact, D.; Riemacker, P.; Nelis, H. and Remon. J. P. (1999): Pharmacokinetics of florfenicol after treatment of pigs with single oral or intramuscular doses or with medicated feed for three days. Vet. Rec. 145: 397-399. 